\title{
Optimization of propagation techniques and timimg for the production of kiwi fruit (Actinidia chinensis) plant at Khyber Pakhtun Khwa Mingora Swat
}

Islam Zeb ${ }^{1 *}$, Muhammad Sajid ${ }^{1}$, Irfan Ullah ${ }^{1}$, Javed Rahman' ${ }^{2}$ Zahoor Ahmad $^{1}$, Farida Bibi ${ }^{1}$,Sadia Khan ${ }^{1}$, Nasra Begum ${ }^{1}$, Shahid Ali ${ }^{1}$ and Aamir Khan ${ }^{1}$

1. Department of Horticulture, The University of Agriculture, Peshawar-25130-Pakistan

2. Agriculture research institute (North) Mingora, Swat-Pakistan

*Corresponding author's email: islamzeb90@ gmail.com

Citation

Islam Zeb, Muhammad Sajid, Irfan Ullah, Javed Rahman, Zahoor Ahmad, Farida Bibi, Sadia Khan, Nasra begum, Shahid Ali and Aamir Khan. Optimization of propagation techniques and timing for the production of kiwi fruit (Actinidia chinensis) at Khyber Pakhtun Khwa Mingora Swat. Pure and Applied Biology. Vol. 6, Issue 3, pp889896. http://dx.doi.org/10.19045/bspab.2017.60094

Received: 12/03/2017 Revised: 13/70/2017

Accepted: 18/07/2017

Online First: 21/07/2017

\section{Abstract}

The experiment was conducted to optimize the propagation techniques (budding \& grafting) with different timing for production of kiwi fruit plant, at Agriculture Research Institute (North) Mingora Swat during 2013. The statistical analysis of the data showed that most of the growth parameters of kiwifruit plants were significantly influenced by different grafting dates and propagation methods. The plants propagated on $9^{\text {th }}$ February showed maximum number of shoots (4.67) graft $^{-1}$, number of leaves (119.00) graft $^{-1}$, leaf area $\left(106.67 \mathrm{~cm}^{2}\right)$, graft growth $(108.5 \mathrm{~cm})$, graft diameter $(4.52 \mathrm{~cm})$, plants survival $(92.00 \%)$ and bud/graft take success $(76.17 \%)$. While the plants propagated on $10^{\text {th }}$ January took more number of days to sprouting (63.10). Similarly, the kiwi plants produced through chip budding showed the maximum days to sprouting (36.93), number of shoots (4.47) graft $^{-1}$, number of leaves $(84.46)$ graft $^{-1}$, graft growth $(87.47 \mathrm{~cm})$, graft diameter $(5.13 \mathrm{~cm})$ and bud/graft take success $(81.00 \%)$. While in case of tongue grafting, the maximum leaf area $\left(101.73 \mathrm{~cm}^{2}\right)$ and plants survival $(77.93 \%)$. The interaction of grafting dates on $9^{\text {th }}$ February and propagation methods as tongue grafting significantly influenced the number of shoots graft ${ }^{-1}$, number of leaves graft ${ }^{-1}$, graft diameter and bud/graft take success while had non-significant effect on number of days to sprouting, leaf area, graft growth and plants survival. It was concluded from the findings of present research that the kiwifruit plants could be propagated through tongue grafting during start to mid-February under the agro climatic condition of swat valley.

Keywords: Tongue grafting; Chip budding; Propagation timing and kiwifruit plant

\section{Introduction}

Kiwi (Actinidia chinensis) is a cross pollinated dioecious fruit in nature that belongs to the family Actinidaceae originated in china. The plant of kiwi fruit is a woody need support climbing shrub or twining vine (liana). A vigorous vine is commonly spread over area of 18 to 24 and 
10 to15 feet in both directions of length and width respectively with height of nine to twelve feet. In crop growing it is maintained on a trellising system [1].

The widespread cultivars of kiwi fruit are elliptical, about the bulk of hefty hen's egg $(4.5-5.5 \mathrm{~cm}$ in diameter and $5-8 \mathrm{~cm}$ in long). It has a stringy brown- green skin and golden or bright green flesh with representation of petite, black edible seeds. The fruit has an exceptional flavor and Alex surface. Nowadays it is money making fruit in most of the countries like New Zealand and Italy. In the year 2011 Italy was the prominent producer with a production of 415,877 tones trailed by New Zealand with the production of 378,500 tones [2]. Additional countries like United States, Chile, Greece, Iran, France, Cambodia, Japan and Canada are the major Kiwi production countries in the world. In Pakistan the production of Kiwi fruit is comparatively up to date. The kiwi fruit wine is grown $1.8 \mathrm{~m}$ (6 feet) trellises, to a great extent resembling to that of grapevine. They are very forceful and typically planted in rows $4.5 \mathrm{~m}$ ( 15 feet) at a distance with the plants set $6 \mathrm{~m}$ ( 20 feet) away from each other in the rows. Full bearing 10-years-old vines can give up 17 to 20 metric tons of fruit ha ${ }^{-1}$ (7 to 9) metric tons acre ${ }^{-1}[3]$. The plants are dioecious, bearing each male or female flower, thus plants requires both sexes to produce fruits. Self-fruiting males are wellknown to be present but produce less attractive fruits. The bulky (1 to 2 inch diameter), white to cream colored flowers are a bit sweet-scented and go out as triplets or single in the leaf axil. Flowering periods prolongs from early May to June, conditional on climatic circumstances [4].

The kiwi fruit can be propagated vegetative by root and leaf cutting under mist irrigation, after treating them with indole butyric acid. They can also be propagated by whip or cleft grafting in the spring or by T- budding in late summer by means of one year old kiwifruit seedlings as rootstocks [5]. Grafting and budding is used in a condition when other reproductive methods like stem cutting, layering or seeds are ineffective and climatic condition is also an unfavorable [6]. Grafting is typically done in early spring or in winter when the scion is dormant, while budding is accomplished in active season when cambium layer is in abundant so it is usually done from June mid to late July, though it may be carried out at other times [7]. Commonly kiwi fruit is propagated through root cutting, tongue grafting, budding i.e. chip or $\mathrm{T}$ budding. Good field nursery can be produced by both of tongue grafting and root cutting, while in budding chip budding is also a good method to reproduce the kiwi plant. The graft take success ratio in tongue grafting is more relatively high as compare to root cutting and $\mathrm{T}$ budding. Tongue grafted plant are more vigorous and healthy as compare to root cutting plants of kiwi plants [8].

\section{Objectives}

To optimize the most suitable time for successful grafting in kiwi fruit plant.

To find out the best propagation method for survival of kiwi fruit plant.

To study the combine effect of propagation methods and time intervals for better production of kiwi plants under the agro climatic condition of swat valley.

\section{Materials and methods}

The experiment to study the "Influence of propagation techniques and timing on the performance of kiwifruit plant" was carried out at Agriculture Research Institute (North) Mingora Swat during 2013. Two propagation methods i.e. Tongue grafting, Chip budding on interval of 15 days $\left(10^{\text {th }}\right.$ January, 25 $5^{\text {th }}$ January, $9^{\text {th }}$ February, $24^{\text {th }}$ February, $11^{\text {th }}$ March) were used and one year old seedling of cultivar Hayward was used as scion, Whereas Bruno was taken as rootstock. 
Each treatment was consisting of 20 grafted plants. So the total number of experimental plants was $30 \times 20=600$. The experiment was laid out in randomized complete block design (RCBD) with two factors and replicated three times. All the cultural practices were kept constant for all the treatments and the data on following parameters were recorded and analyzed statistically.

\section{Days to sprouting}

Data on the subject of days to sprouting was collected from 5 randomly selected plants for each treatment in every replication by counting from the day of grafting to the date of sprouting.

\section{Number of shoots graft $^{-1}$}

The number of shoots of randomly taken five plants in each replication for each treatment was counted and then there means were found out.

\section{Number of leaves graft $^{-1}$}

The number of leaves graft ${ }^{-1}$ was counted in each replication for each treatment of five randomly taken plants and then calculated their average accordingly.

\section{Leaf area $\left(\mathrm{cm}^{2}\right)$}

The leaves were taken randomly from each treatment in each replication and leaf area in centimeter square was measured with the help of leaf area measuring meter and then calculated their average.

\section{Graft growth (cm)}

With the help of measuring tape the length of scion growth of five randomly taken plants was recorded from the basal portion of the scion to the tip of the scion for each treatment in each replication and their average was noted.

\section{Graft diameter $(\mathbf{c m})$}

The graft diameter $(\mathrm{cm})$ of scion growth at uniform height of five randomly taken plants for each treatment in each replication was measured with the help of Vernier caliper and calculated the mean.

\section{Plant survival percentage}

In each replication the percent plant survival for each treatment was recorded with the formula given below.

Percent plants survival $=\underline{\text { Number of survived plant }}$ x 100 Total number of plant

Bud/ Graft take success (\%)

The data for percent bud/graft takes success was recorded after complete sprouting and successful growth of scion at the end of the growing season by using the formula.

Percent bud success $=$ Number of budded plants survived $\times 100$ Total number of plants budded

Percent graft success $=$ Number of grafted plants survived $\times 100$ Total number of plants grafted

\section{Results and discussion}

\section{Number of days to sprouting}

Mean values of the data revealed that the propagation on different dates significantly affected the number of days to sprouting of kiwifruit plant. The highest number of days (63.00) to sprouting were noted in kiwifruit plant propagated on $10^{\text {th }}$ January, 2013, which was statistically different from rest of propagation dates, followed by number of days (51.00 and $31.00)$ to sprouting in plants propagated on $25^{\text {th }}$ January and $9^{\text {th }}$ February, 2013 respectively. Similarly, the more number of days (37.00) to sprouting were noted in kiwifruit plants propagated through chip budding. Whereas the less number of days (34.00) to sprouting were recorded in plants that propagated through tongue grafting. The results are in concordance with [9] who observed that after 15-20 days of grafting the callus connections were established and during this time it should not be exposed to both high and low temperatures [10] also noticed that in case of budding the ambient temperature $\left(15-18^{\circ} \mathrm{C}\right)$ should be needed for rapid and well attachment of scion and rootstock, while on other hand the budding might took long time or may be failed due to low temperature during January or non-consistent temperature. The data regarding numbers of sprouts per cutting are presented in Table 1. 
Table 1. Graft diameter (cm), plant survival (\%) and bud/ graft take success (\%) in kiwifruit plant as affected by propagation techniques and timing

\begin{tabular}{|l|c|c|c|}
\hline Grafting dates & Graft diameter $(\mathbf{c m})$ & Plant survival (\%) & Bud/ Graft take success (\%) \\
\hline 10 January & $3.82 \mathrm{~d}$ & $54.00 \mathrm{e}$ & $56.17 \mathrm{~d}$ \\
\hline 25 January & $4.15 \mathrm{c}$ & $61.00 \mathrm{~d}$ & $61.50 \mathrm{c}$ \\
\hline 09 February & $4.52 \mathrm{a}$ & $92.00 \mathrm{a}$ & $76.17 \mathrm{a}$ \\
\hline 24 February & $4.27 \mathrm{~b}$ & $88.17 \mathrm{~b}$ & $73.67 \mathrm{a}$ \\
\hline 11 March & $4.08 \mathrm{~d}$ & $83.67 \mathrm{c}$ & $66.33 \mathrm{~b}$ \\
\hline LSD $\boldsymbol{\alpha}$ 0.05 & 0.03 & 2.48 & 2.65 \\
\hline Propagation techniques & $3.21 \mathrm{~b}$ & $77.93 \mathrm{a}$ & $52.53 \mathrm{~b}$ \\
\hline Tongue grafting & $5.13 \mathrm{a}$ & $73.60 \mathrm{~b}$ & $81.00 \mathrm{a}$ \\
\hline Chip budding & 0.02 & 1.57 & 1.68 \\
\hline LSD $\boldsymbol{\alpha}$ 0.05 & 0.04 & $\mathrm{NS}$ & 3.75 \\
\hline Interaction (DXT) & \multicolumn{4}{|l|}{}
\end{tabular}

Mean followed by similar letter(s) in column do not differ significantly. D x T = Interaction between grafting dates and propagation techniques

Number of shoots graft $^{-1}$

The data regarding number of shoot graft $^{-1}$ are presented in Table 2 showed that the different dates significantly affected the number of shoots graft $^{-1}$ of kiwifruit plant. The more number of shoots (4.67) graft $^{-1}$ were counted in kiwifruit plant grafted on $9^{\text {th }}$ February which was statistically at par with number of shoots (4.33 and 4.17) graft $^{-1}$ in plants propagated on $24^{\text {th }}$ February and $11^{\text {th }}$ March, 2013 respectively. As regard to grafting methods, there is a significant difference among the means. The more number of shoots (4.47) graft $^{-1}$ were noted in kiwifruit plant propagated through chip budding. Similarly, the interaction between the propagation methods and grafting dates significantly affected the number of shoot graft $^{-1}$ of kiwifruit plant. The more number of shoots (5.67) graft $^{-1}$ were recorded in kiwifruit plants propagated through chip budding on $24^{\text {th }}$ February, 2013. Whereas, less number of shoots (2.67) graft $^{-1}$ were counted in kiwifruit plant propagated through chip budding and tongue grafting on $10^{\text {th }}$ January, 2013. Similar results were presented by Rayya et al. [11] who observed that the chip budding gave maximum number of branches in almonds cv. Neplus Ultra by comparing it with other methods like T-budding, cleft and side grafting.

Table 2. Days to sprouting, number of shoots graft $^{-1}$ and number of leaves graft $^{-1}$ leaf area $\left(\mathrm{cm}^{2}\right)$ and graft growth (cm) in kiwifruit plant as affected by propagation techniques and timing

\begin{tabular}{|c|c|c|c|c|c|}
\hline Grafting dates & $\begin{array}{l}\text { Days to } \\
\text { sprouting }\end{array}$ & $\begin{array}{l}\text { Number of } \\
\text { shoots graft }^{-1}\end{array}$ & $\begin{array}{l}\text { Number of } \\
\text { leaves graft }^{-1}\end{array}$ & $\begin{array}{l}\text { Leaf area } \\
\left(\mathrm{cm}^{2}\right)\end{array}$ & $\begin{array}{l}\text { Graft growth } \\
\text { (cm) }\end{array}$ \\
\hline 10 January & $63.00 \mathrm{a}$ & $2.67 \mathrm{c}$ & $53.17 \mathrm{~d}$ & $89.00 \mathrm{c}$ & $59.67 \mathrm{e}$ \\
\hline 25 January & $51.00 \mathrm{~b}$ & $3.33 \mathrm{~b}$ & $39.33 \mathrm{e}$ & $92.83 \mathrm{c}$ & $66.67 \mathrm{~d}$ \\
\hline 09 February & $31.00 \mathrm{c}$ & $4.67 \mathrm{a}$ & $119.00 \mathrm{a}$ & $106.67 \mathrm{a}$ & $108.50 \mathrm{a}$ \\
\hline 24 February & $19.00 \mathrm{~d}$ & $4.33 \mathrm{a}$ & $105.50 \mathrm{~b}$ & $104.67 \mathrm{a}$ & $99.00 \mathrm{~b}$ \\
\hline 11 March & $13.00 \mathrm{e}$ & $4.17 \mathrm{a}$ & $80.83 c$ & $98.33 \mathrm{~b}$ & $79.50 \mathrm{c}$ \\
\hline LSD $\propto 0.05$ & 3.13 & 0.60 & 4.1 & 4.35 & 3.73 \\
\hline \multicolumn{6}{|c|}{ Propagation techniques } \\
\hline Tongue grafting & $34.00 \mathrm{~b}$ & $3.20 \mathrm{~b}$ & $74.66 b$ & $101.73 \mathrm{a}$ & $77.87 \mathrm{~b}$ \\
\hline Chip budding & $37.00 \mathrm{a}$ & $4.47 \mathrm{a}$ & $74.66 \mathrm{~b}$ & $94.87 \mathrm{~b}$ & $87.47 \mathrm{a}$ \\
\hline LSD $\alpha 0.05$ & 1.99 & 0.38 & 2.6 & 2.75 & 2.36 \\
\hline Interaction (DXT) & $\mathrm{NS}$ & 0.85 & 5.9 & NS & $\mathrm{NS}$ \\
\hline
\end{tabular}

Mean followed by similar letter(s) in column do not differ significantly. D x T = Interaction between grafting dates and propagation techniques 


\section{Number of leaves graft $^{-1}$}

The mean data of the Table 2 describes a significant variation and effect the number of leaves graft ${ }^{-1}$ of kiwifruit plant. The more number of leaves (119.00) graft $^{-1}$ were recorded in kiwifruit plant propagated on $9^{\text {th }}$ February which was statistically varied from rest of mean values followed by number of leaves (105.50 and 80.83) graft $^{-1}$ in kiwifruit plant propagated on $24^{\text {th }}$ February and 11 March, 2013 respectively. The less number of leaves (39.33) graft $^{-1}$ were counted in plants produced on $25^{\text {th }}$ January, 2013. As concerned to grafting methods it also significantly affected the number of leaves graft $^{-1}$ of kiwifruit plant. The more number of leaves (84.46) graft $^{-1}$ were noted in kiwifruit plant produced through chip budding. The interaction between grafting methods and dates showed a significant effect on number of leaves graft $^{-1}$ of kiwifruit. The maximum number of leaves (134.60) graft $^{-1}$ were recorded in kiwifruit plant propagated through chip budding on $9^{\text {th }}$ February while the minimum number of leaves (36.67) graft $^{-1}$ were noted in plants produced through chip budding on $25^{\text {th }}$ January, 2013. The similar results regarding number of leaves were observed by Rayya et al. [11] in almond fruit trees that were propagated through chip budding technique during spring (February, March). Same increase in number of leaves was also observed by Safia et al. [12] in pecan grafted through cleft grafting method during February.

\section{Leaf area $\left(\mathrm{cm}^{2}\right)$}

The mean values of the Table 2 declared that the different dates significantly affected while their interaction showed nonsignificant differences for leaf area of kiwifruit plants. The large leaf area (106.67 $\mathrm{cm}^{2}$ ) was recorded in plants propagated on $9^{\text {th }}$ February which was statistically at par with plants propagated on $24^{\text {th }}$ February $\left(104.67 \mathrm{~cm}^{2}\right)$. The small leaf area $(89.00$ $\mathrm{cm}^{2}$ ) was noted in kiwifruit plant propagated on $10^{\text {th }}$ January, 2013. Similarly, the grafting methods also significantly affected the leaf area of kiwifruits. The large leaf area $\left(101.73 \mathrm{~cm}^{2}\right)$ was noted in kiwifruit plant propagated through tongue grafting while the small leaf area $\left(94.87 \mathrm{~cm}^{2}\right)$ was recorded in kiwifruit plant propagated through chip budding technique [13] observed that appropriate time of propagation, environmental conditions and compatibility of scion and rootstock resulted in wellestablished union of grafted/budded plant. Tongue grafting provide a union in line with vascular tissues (xylem and phloem) that leads to a good translocation of water and nutrient to plant which resulted in good vegetative growth. The similar results were also observed by Mannan et al. [14] in jack fruit who reported that the plants were more vegetative more vigorous and produced large size of leaves when propagated during spring.

\section{Graft growth (cm)}

The Table 2 stated that the different dates significantly influenced the graft growth of kiwifruit plant. The tallest $(108.5 \mathrm{~cm})$ graft was measured in kiwifruits that were propagated on $9^{\text {th }}$ February, 2013, which was statistically in contrast to the rest of mean values, followed by graft growth $(99.00$ and $79.50 \mathrm{~cm})$ in plant propagated on $24^{\text {th }}$ February and 11 March 2013 respectively, while the shortest $(59.67 \mathrm{~cm})$ graft was noted in plants propagated on $10^{\text {th }}$ January 2013. Similarly, the methods of propagation also showed a significant effect of graft growth of kiwifruit plant. The longest $(87.47 \mathrm{~cm})$ graft was noted in kiwifruits that were propagated through chip budding. The increase in shoot length might be due to a stronger graft union and development of the normal xylem and phloem vessels at the sight of graft union that regulates the movement of available water and nutrients from soil and thereby 
enhanced the active vegetative growth [15]. The proper supply of growth regulating hormones (auxin) due to well joined union also improves the growth and development of shoot/scion [16]. Other researchers like [17-19] recommended the technique of chip budding in kiwifruit as it enhanced the shoot length of propagated plant [20-23] also observed the superiority of chip budding against $\mathrm{T}$ budding in kiwifruit.

\section{Graft diameter $(\mathrm{cm})$}

The Table 1 showed that the different dates significantly influenced the graft diameter of kiwifruit plant. The maximum $(4.52 \mathrm{~cm})$ graft diameter was recorded in plant propagated on $9^{\text {th }}$ February which is statistically varied from rest of dates, followed by graft diameter (4.27 and 4.15 $\mathrm{cm}$ ) in plants propagated on $24^{\text {th }}$ February and $25^{\text {th }}$ January, 2013, respectively. The minimum graft diameter $(3.82 \mathrm{~cm})$ was measured in kiwifruit propagated on $10^{\text {th }}$ January. Similarly, the grafting methods also significantly impacted the graft diameter of kiwifruit plant. The large graft $(5.13 \mathrm{~cm})$ was measured in kiwifruits propagated through the practice of chip budding. The interactive effect between different dates and methods also significantly affected the graft diameter. The maximum graft diameter $(5.41 \mathrm{~cm})$ was noted in kiwifruit propagated through chip budding on $9^{\text {th }}$ February while the minimum graft diameter $(2.82 \mathrm{~cm})$ was measured in plants propagated through tongue grafting technique on $10^{\text {th }}$ January. The grafting performed in dormant bud situation may enhance the better vegetative growth and resulted in the large graft diameter. Also, the grafting performed in growing season produced the good results [20]. Comparing other various methods of budding and grafting [11, 15, 24] also obtained the maximum growth of plants propagated through chip budding. Similar results on different fruit species were also observed by Polak and Kaşka [21] in loquats and [25] on kiwifruit.

\section{Plant survival percentage}

The mean data in Table 1 resulted that the different dates significantly influenced the plant survival percentage of kiwifruit plant. The highest $(92.00 \%)$ plant survival was recorded in the kiwifruit plants that are propagated on $9^{\text {th }}$ February, which is statistically varied from rest of mean values, followed by plant survival $(88.17$ and $83.67 \%$ ) noted in plants that were propagated on 24 February and 11 March, 2013, respectively. The lowest (54.00\%) plant survival was noted in kiwifruits that were propagated on $10^{\text {th }}$ January, 2013. Similarly, the different methods of propagation also significantly influenced the plant survival percentage of kiwifruit plant. The highest $(77.93 \%)$ plant survival was recorded in kiwifruit plants that were propagated through tongue budding technique while the lowest plant survival $\mathbf{7} 73.60 \%)$ was noted in kiwifruit which were associated with chip budding technique [26] stated that grafting in February offer favorable environmental conditions which is helpful for the healing process of the graft wounds and thus causes in development of normal vascular tissues at the graft union and enhances the plant survival. While [27] suggested that grafting can be done in any time during the dormant season but the successful healing of graft union took place when it is done early spring and monsoon season. The results are also in line with the findings of [13] who observed the highest plant survival during spring season in loquat fruit grafting.

\section{Bud/ graft take success}

Mean value in Table 1 for different dates showed a significant effect on bud/graft take success of kiwifruit plants. The highest $(76.17 \%) \mathrm{bud} / \mathrm{graft}$ take success was noted in kiwifruits plants propagated on 9 February, 2013 followed by plant survival 
(88.17 and 83.67\%) noted in plants that were propagated on 24 Feb and 11 March, 2013. Similarly, the grafting methods also significantly influenced the bud/graft take success in kiwifruit plants. The maximum $(81.00 \%)$ bud/graft take success was observed in kiwi plants that were propagated through chip budding. The interaction between grafting techniques on different dates also showed a significant affect. The highest bud/graft take success $(92.33 \%)$ was noted in plants that were propagated through chip budding on 24 February. In case of bud/graft take success, the most responsive and superior technique was chip budding. This might be due to the high level of callus formation around the graft location [20]. The results are in line with the findings of $[23,24,28]$ who suggested the chip budding for propagation of kiwifruits. In addition to chip budding, [11] also recommended Tbudding in kiwifruits.

\section{Conclusions}

The kiwi plants propagated on $9^{\text {th }}$ February showed maximum number of shoots, leaves graft $^{-1}$, leaf area, graft growth, graft diameter, plant survival and bud/graft take success. While the plants that were propagated on $10^{\text {th }}$ January took more days to sprouting and had less number of shoots graft $^{-1}$, leaf area, graft growth, graft diameter, plant survival and bud/graft take success. Maximum days to sprouting, number of shoots graft ${ }^{-1}$, leaves graft ${ }^{-1}$, graft growth, graft diameter and bud/graft take success with minimum leaf area and plant survival were obtained when the kiwi plants propagated through chip budding. The highest leaf area, plant survival percentage and less number of days to sprouting, number of shoots, leaves graft $^{-1}$, graft growth, graft diameter and bud/graft take success were obtained when the kiwi plants propagated through tongue grafting.

\section{Recommendations}

On the basis of results recoded and the above conclusions the following recommendations were made. The kiwifruit plant could be propagated through tongue grafting during mid to late February under the agro climatic conditions of swat valley.

\section{Authors' contributions}

Conceived and designed the experiments: J Rahman, Performed the experiments: I Zeb, I Ullah \& Z Ahmad, Analyzed the data: S Ali, A Khan \& I Ullah, Contributed reagents/ materials/ analysis tools: $\mathrm{F}$ Bibi, $\mathrm{N}$ Begum, S Ali \& A khan, Wrote the paper: I Zeb \& I Ullah.

\section{References}

1. Lee R (1991). Uncommon Fruits worthy of Attention. Addison of Wesley 122-138.

2. FAOSTAT (2010). Food and agriculture organization of the united nation http:faostat.org.site/339/ default. Aspx upsated jan 2010.

3. Beutel JA, Winter FH, Manners SC \& Miller MW (1976). A new crop for California. Kiwifruit California Agric. 30(10): 5-7.

4. Ferguson AR (2003). Kiwi fruit Production in China. New Zeland J crop Hort Sci 31: 97-202.

5. Beutel J (1975). Kiwi propagation. Proceeding International Plant Propagation Society 25: 63-67.

6. Kumar GNM (2011). Propagation of Plants by Grafting and Budding Washington State. Uni. Pp. 1.

7. Leonard, Stoltz P \& Strang J (2005). Reproducing Fruit Trees by Graftage, Budding and Grafting. Corporative extension service uni Kentucky Eng pp.1.

8. Beutel J \& Davis UC (1981). Kiwifruit (Actenedia chinensis) Propagation. Extension Pomologist July pp 1-2.

9. Hartman HT, Kester D \& Davies PT (1990). Plant propagation principles and practices. 5th Edi. Regents/Prentice Hall, Englewood Cliffs, New Jersey.

10. Tuzcu O, Dogrular HA, Demirkol A, Kaplankiran M \& Yesiloglu T (1987). 
Determinations of the most suitable budding and grafting type and time for some important avocado (Persea americana) varieties under Antalya ecological conditions. Derim 4: 110-125.

11. Rayya A, Kasim MS, Shaheen NE, Yehia MA \& Ali EL (2009). Morphological and anatomical evaluation of different budding and grafting methods and times of Neplus Ultra Almond (Prunus dulcis) Cultivar. J App Sci Res 5(3): 253-262.

12. Safia ATA, El-Taweel AA \& Ali AA (2011). Studies on the vegetative propagation of pecan (Carya illinoinensis) grafting by cleft grafting method under open field conditions. J Agric Res 37(1): 141-161.

13. Abassi N, Hafiz IA, Qureshi AA, Ali I \& Mahmood SR (2014). Evaluating the success of vegetative propagation Techniques in loquat (Eriobotrya japonica) cv. Mardan . Pak J Bot 46(2): 579-584.

14. Mannan MM, Islam MM \& Khan SAKU (2006). Effects of methods of grafting and age of rootstock on propagation of OFFSeason germplasm of Jackfruit (Artocarpus heterophyllus). Khulna. Uni Studies 7(2): 77-82.

15. Kim IS, Hwang JL, Han KP \& Lee KE (1988). Studies on the germination of seeds in native Actinidiaspecies. Hort Abs 58(1): 7336.

16. Paul G \& Gunaratum GM (1992). Propagation of mango by new techniques. Acta Hort 46(2): 211-218.

17. Celik H, Zenginbal H \& Ozcan M (2006). Effect of budding performed by hand and with manual grafting unit on kiwifruit (Actenedia chinensis) propagation in the field. Hort Sci (Prague) 33(2): 57-60.

18. Scene DS, Shephero HR \& Howard BH (1983). Characteristic anatomy of union formation in $\mathrm{T}$ and chip budded fruit and ornamental trees. J Horti Sci 58: 295-299.
19. Peruzzo EL and Dalbo MA (1992). Propagation of grapevines (Vitis vinifera) and kiwifruits (Actenedia chinensis) by fork grafting. Agropecuaria-Catarinense 5: 45-47.

20. Zenginbal H, Ozcan M, Hazneder A \& Demir T (2007). Comparisons of Methods and Time of Budding in Kiwifruit (Actinidia deliciosa) A. Chev. Int J Nat Eng Sci 1: 23-28.

21. Polak AA \& Kaşka N (1992). Anatomical and histological studies on the shield, patch and chip buddings in loquats (Eribotrya japonica Lindl). Turk $J$ Agric Forest 16: 529-541.

22. Kuden A (1988). Investigation on different budding methods temperate-zone fruit seedling in subtropical conditions. Uni. Çukurova, Inst Applied Sci, Adana.

23. Spirovska R, Stamenkov M \& Markovski M (1993). The effect of time and method of grafting on the growth of (Actenedia chinensis) Pl. Transplants. Hort Abst 63(3): 1815.

24. Chandel JS, Negi KS \& Jindal KK (1998). Studies on vegetative propagation in kiwi (Actinidiadeliciosa Chev) Indian J Hort 55(1): 52-54.

25. Zenginbal H (1998). Propagation of kiwifruits by buddings under Samsun ecological conditions. Uni Ondokuz Mayis, Inst of Applied Sci Samsun

26. Awasthi DN, Sinha MM, Srivastava RP and Misra RS (1982). Evaluation of epicotyls grafting in walnut (Juglans regia) in relation to success and survival. Prog Hort 14: 178-179.

27. Mian IH (1971). A new approach to loquat (Eriobotrya japonica) propagation. $J$ Agric Res Publ 9(1).

28. Lawes GS \& Sim BL (1980). An analysis of factors affecting the propagation of kiwifruit (Actenedia chinensis). The Orchardist of New Zealand 53: 88-90. 